\title{
The Nordic Origins of the Iliad and Odyssey: An Up-to-date Survey of the Theory
}

\author{
By Felice Vinci*
}

\begin{abstract}
An up-to-date survey of the theory proposed in "The Baltic Origins of Homer's Epic Tales" is presented here. The real setting of the Iliad and Odyssey can be identified not as the Mediterranean Sea, where it proves to be undermined by many incongruities, but rather in the north of Europe. The oral sagas that originated the two poems came from the Baltic regions, where the Bronze Age flourished in the 2nd millennium BC and where many Homeric places, such as Troy and Ithaca, can still be identified today. The blond seafarers who founded the Mycenaean civilization in the Aegean in the 16th century BC brought these tales from Scandinavia to Greece after the end of the climatic optimum. These peoples then rebuilt their original worldwhere the Trojan War and many other mythological events had taken place - farther south in Mediterranean waters, transferring significant names from north to south. Through many generations, they preserved the memory of the heroic age and the feats performed by their ancestors in their lost Hyperborean homeland, until the oral tradition was put into written form around the 8th Century BC, when alphabetical writing was introduced in Greece. This new prospect can open new developments as to the European prehistory and the dawn of the Greek civilization.
\end{abstract}

Keywords: Homer, Bronze Age, Nordic, Iliad, Odyssey

\section{The Northern Features of Homer's World}

Northern Features of Climate, Clothes, Food, and Vessels

Homer's world presents northern features. The climate is normally cold and unsettled, very different from what we expect in the traditional Mediterranean setting. The Iliad dwells upon violent storms (i.e., in Il. IV: 275278, XI: 305-308, XIII: 795-799), torrential rain and disastrous floods (Il. V: 87-91, XI: 492-495, XIII: 37-141, XVI: 384-388), and often mentions snow (Il. XII, 156-158), even on lowlands (Il. XII: 278-286, X: 6-8, XV: 170-171; XIX: 357-358, III: 222). Fog is found everywhere, e.g., in the "misty sea" (Od. V, 281), and also in Troy (Il. XVII: 368), Scherie (Od. VII, 41-42), Ithaca (Od. XIII: 189), the Cyclopes' land (Od. IX: 144), and so on. As regards the sun, the Iliad hardly ever refers to its heat or rays; the Odyssey never mentions the sun warmth in Ithaca, though it refers to the sailing season. As to the seasons, there is a parallel between Homer, who mentions only three seasons: winter, spring and summer, and Tacitus's Germans, for whom "winter, spring and summer have meaning and names, but they are unaware of the name and produce of autumn" (Germania, 26: 4).

\footnotetext{
${ }^{*}$ Independent Researcher, Writer, Italy.
} 
Clothes described in the two poems are consistent with a northern climate and the finds of the Nordic Bronze age. In the episode of the Odyssey in which Telemachus and Peisistratus are guests at Menelaus's house in Sparta, the two young men get ready for lunch after a bath: "They wore thick cloaks and tunics" (Od. IV: 50-51). The same is said of Odysseus when he is a guest at Alcinous's house (Od. VIII: 455-457). Similarly, Nestor's cloak is "double and large; a thick fur stuck out" (Il. X: 134) and, when Achilles leaves for Troy, his mother thoughtfully prepares him a trunk "filled with tunics, wind-proof thick cloaks and blankets" (Il. XVI: 223-224). Those "thick cloaks and tunics" can be compared to the clothes of a man found in a Danish Bronze Age tomb: "The woolen tunic comes down to the knees and a belt ties it at the waist. He also wears a cloak, which a bronze buckle pins on his shoulder" (Bibby 1966: 245). Also Odysseus wears "a golden buckle" (Od. XIX: 226) on his cloak, and "a shining tunic around his body like the peel on a dry onion" (Od. XIX: 232233); all of this fit what Tacitus says of Germanic clothes: "The suit for everyone is a cape with a buckle (...) The richest are distinguished by a suit (...) which is close-fitting and tight around each limb" (Germania 17: 1).

Regarding food, it's remarkable that fruit, vegetables, olive oil, olives, figs never appear on the table of Homer's heroes. Their diet was based on meat (beef, pork, goat, and game), much like that of the Vikings, who "ate meat in large quantities, so much so that they seemed to regard the pleasure of eating meat as one of the joys of life" (Pörtner 1996: 207). Homer's characters had a hearty meal in the morning: "In the hut Odysseus and his faithful swineherd lit the fire and prepared a meal at sunrise" (Od. XVI: 1-2), like Tacitus's Germans: "As soon as they wake up (...) they eat; everyone has his own chair and table" (Germania 22: 1). This individual table (trapeza) is typical of the Homeric world, too (Od. I: 138).

One should also note that, while pottery tableware was prevalent in Greece, the Nordic world was marked by "a stable and highly advanced bronze founding industry" (Fischer-Fabian 1985: 90), which squares with Homer's poems, which mention only vessels made of metal: "A maid came to pour water from a beautiful golden jug into a silver basin" (Od. I, 136-137); wine was poured "into gold goblets" (III: 472) and "gold glasses" (I: 142). When a vessel felt to the ground in Odysseus' palace, instead of breaking it "boomed" (bombēse, Od. XVIII: 397). Also lamps (XIX: 34), cruets (VI: 79), and urns (Il. XXIII: 253) were made of gold. As to the poor, Eumaeus the herdsman pours wine for his guests "into a wooden cup" (kissybion, Od. XVI: 52), like the cup Odysseus gives Polyphemus (Od. IX: 346). Wood, of course, is the cheapest material in the north (Estonia and Latvia have an ancient tradition of wooden beer tankards). 


\section{Nordic Customs and Archaism of Homer's World}

There are many remarkable parallels between the Homeric Achaeans and the Nordic world, in the fields of their social relations, interests, lifestyles, and so on, despite the time gap. E.g., Homer's habit of giving things and slaves a value in "oxen" - a new vase, decorated with flowers, was worth "the price of an ox" (Il. XXIII, 885); a big tripod was worth twelve oxen (Il. XXIII: 703); Ulysses' nurse Eurycleia had cost twenty oxen (Od. I: 431), and so on - is comparable to the fact that, during the first Viking Age, cows were still used "as the current monetary unit" (Pörtner 1996: 199). A statement from Tacitus bridges these two distant epochs: "Cattle and oxen (...) are the Germans' only and highly valued wealth" (Germania, 5, 1). Besides, the prominence of oxen in the economy of the Homeric world is another argument in favour of the Nordic setting, while in the Greek world other kinds of livestock are more important (one should also consider how important were beef and pork in Achaeans' diet).

Still on Tacitus, Karol Modzelewski, by quoting a custom reported in Germania, 11, writes: "The mention of assembly decisions taken by a peculiar acclamation method, consisting in brandishing spears, is confirmed by the codifications, dating back to the $12^{\text {th }}$ century, of the Norwegian juridical traditions, where this rite is called vapnaták" (Modzelewski 2008: 33). It is remarkable that the custom of going armed with spear to the assembly is found in Homer: Telemachus "went to the assembly, he held the bronze spear" (Od. II: 10). Thus a custom dating back to the Homeric world was still present in Viking Norway of the $12^{\text {th }}$ century.

One should also note that Odysseus' ship had a removable mast, a feature typical of all Homeric vessels: both the Iliad (I: 434, 480) and Odyssey (II: 424, VIII: 52) confirm that setting up and taking down the mast were customary at the beginning and the end of each mission. This feature was also typical of the Viking ships, which lowered the mast whenever there was the risk of sudden gusts or ice formation, which could cause the ship to capsize. Another structural feature typical of Viking ships, the flat keel, is found also in Homeric ones, as one can infer from the passage narrating Ulysses' arrival in Ithaca, where the Phaeacian ship "mounted the beach by half the length" (Od. XIII: 114).

Another peculiar custom of the Homeric heroes is that they got off the chariots and left them aside during the duels: e.g., the Trojan hero Asius used to fight "on foot in front of his puffing horses, which the charioteer kept all the time behind him" (Il. XIII: 385-386). Scholars agree that this way of using the chariots seems to be absurd and senseless: "No one has ever fought like the heroes of Homer. They are led to battle in chariot, then they jump off to fight against the enemy. All that we know about the battle chariots in Eastern Mediterranean protests against this view of things" (Vidal-Naquet 2013: 573). However, what looks odd in the Mediterranean fits the Nordic world: according to Diodorus of Sicily, the Celts "employed two-horse chariots, each with his coachman and warrior, and, when they confronted each other in war, 
they used to throw the javelin, then they came down from the chariot and fought with the sword" (Historical Library 5: 29). Still Diodorus writes that "Brittany is said to be inhabited by native tribes conforming to their ancient way of life. In war they use chariots, like the ancient Greek heroes in the Trojan war" (Historical Library 5: 21). Julius Caesar adds other details upon the Britains: "When they have worked themselves in between the troops of horse, leap from their chariots and engage on foot. The charioteers in the mean time withdraw some little distance from the battle, and so place themselves with the chariots that, if their masters are overpowered by the number of the enemy, they may have a ready retreat to their own troops. Thus they display in battle the speed of horse, together with the firmness of infantry" (De bello Gallico IV: 33).

So, the chariot fightings narrated by the Iliad are not absurdities due to the supposed ignorance of the poet; instead, Homer must be considered the only extraordinary witness of the Nordic Bronze Age, whose archaic customs survived in Britain until Caesar's age.

This confirms what Stuart Piggott writes: "The nobility of the [Homeric] hexameters should not deceive us into thinking that the Iliad and the Odyssey are other than the poems of a largely barbarian Bronze Age or Early Iron Age Europe. There is no Minoan or Asiatic blood in the veins of the Grecian Muses (...) They dwell remote from the Cretan-Mycenaean world and in touch with the European elements of Greek speech and culture (...) Behind Mycenaean Greece (...) lies Europe" (Piggott 1968: 126). Besides, according to Geoffrey Kirk, the Homeric poems "were created (...) by a poet, or poets, who were completely unaware of the techniques of writing," (Kirk 1989: 78) and "a recent linguistic argument suggests that the Homeric tmesis, i.e. the habit of separating adverbial and prepositional elements that were later combined into compound verbs belongs to a stage of language anterior to that represented in the Linear B tablets. If so, that would take elements of Homer's language back more than five hundred years before his time" (Kirk 1989: 88-89).

That's why "there is an absolute difference both in extension and quality between the Mycenaean society and Iliad's" (Codino 1974: IX): Homer's civilization appears more archaic than the Mycenaean one. There is also the odd case of Dionysus, who is an important god both in the Mycenaean period and in classical Greece, but is almost unknown in Homer: Homer's world, therefore, probably preceded the Mycenaean civilisation, instead of following it.

\section{Greeks Myths and Gods in the North}

Károly Kerényi underlines the similarities between the myth of the birth of Helen from a fen-bird egg and some legends of the "Finno-Ugric peoples from Russia" (Kerényi 1979: 36). He refers to the Esthonian epic poem Kalevipoeg, where one can find the tale on the birth of "beautiful Linda" from an egg found by chance. Another case of convergence is the mythical wedding of Zeus and Leda, Helen's parents, in the features of a swan and a wild goose respectively 
(Kerényi 1979: 35). Helen's abduction has a parallel in Norse mythology, where Snion, son of the king of Denmark, abducted the beautiful queen of Sweden, which aroused a war (Gesta Danorum VIII, XI: 2). Besides, the Norse Valkyries, who bring the souls of slain warriors to Valhalla, can be compared to the Homeric "dreadful Kēr", who, in the battlefield, "one moment seized a freshly wounded man, then another still unhurt, or she dragged a corpse by its foot through the fray. She wore a cloak around her shoulders, which was red with human blood" (Il. XVIII: 535-538).

Still in Eastern Baltic, "Near Ragnit, Lithuania, reapers leave the last tuft of wheat standing and say: 'Old Boba is sitting there.' Then a young mower sharpens his sickle and cuts the tuft with a stroke. People say that he cut Boba's head" (Frazer 1973: 77). Boba is Baubo, Trittolemus's mother, the Orphic goddess connected with Demeter, the Greek goddess of crops.

Besides, Saxo Grammaticus often mentions Curetia - now Kurland, a district of Latvia - whose name derives from an ancient people known as the Curians. Saxo calls its inhabitants "Curetes" (Gesta Danorum I, VI: 7), comparable to Homer's Curetes ${ }^{1}$ (Il. IX: 529-589), whom Greek mythology links to Zeus's birth. As to Zeus himself, just in that region there is "the figure of a supreme god called Dievas in Lithuania and Dievs in Latvia. In local folklore he curiously shows features typical of Hellenic Zeus" (Prampolini 1954: 460).

Saxo links the Curetes to Hadingus, a legendary Danish king, whose adventures recall stunningly those of Odysseus: he resorts to a stratagem to conquer a city, is seduced by a sorceress skilled at shapeshifting, is recognized by a woman because of a scar in the calf, is fond of the sea and ships, kills a sea monster and, therefore, is persecuted by the gods; he visits Hell (Gesta Danorum I, VIII: 2-27); besides, Odin gives advice and helps him, just as Athena does for Odysseus.

On the other hand, a Nordic Odysseus - who, according to Homer, was "fair-haired" (Od. XIII: 399, 431) - is mentioned both by Plutarch, who says that Ogygia lay in the North Atlantic (De Facie quae in Orbe Lunae apparet 941a), and Tacitus, who claims that he sailed the Northern seas (Germania, 3.2). Probably these tales reached Rome in the first century AC, the time of Plutarch and Tacitus, owing to the expeditions of the Romans to Great Britain: they could derive from the oral tradition of the Celts. Actually, Plutarch might refer to them when, by examining the localization of Ogygia, claims: "The barbarians hand down..." (De Facie 941a).

The favourite themes of the Celtic bards included adventures (echtra) beyond human bounds, and wanderings (immram) towards the paradisiacal islands in the middle of the ocean, where divine women refreshed and made love with the heroes who arrived there, offering them immortality and everlasting youth. This is how the queen of one of these fabulous islands addresses a hero after he goes ashore: "If you remain here, old age will not catch you. You'll be young as you are now, and will live for ever" (Markale 1982: 318). All of this is identical to the outlying island of the goddess

${ }^{1}$ Cf. Ilze Rūmniece 2013. 
Calypso, who promises to make Odysseus "immortal and ageless forever" (Od. V: 136, VII: 257). Besides, the Immram curaig Máele Dúin ("The Voyage of Máel Dúin's Ship") begins with a journey in search of the protagonist's father, like Telemachus' journey, followed by a series of adventures like Odysseus'. So, it is no coincidence that "in 1892 (...) Arbois de Jubainville described the Odyssey as an immram and later, in 1899, he confronted the Celtic society with the Homeric one" (Bendelli 2013: 550).

The oral tradition of the Druids could also be at the origin of the Irish work in Gaelic language Merugud Uilix maicc Leirtis ("Wanderings of Odysseus son of Laertes"), dating back to the $13^{\text {th }}$ century, where one can find a mix of themes coming from both the Odyssey and Irish folklore. It remains debatable whether such similarities with the Odyssey came from the classical epic, or from an independent tradition to which Plutarch and Tacitus made reference when they mentioned the Nordic Odysseus. In this respect, one should consider that there are details of the Merugud Uilix maicc Leirtis which diverge from the Odyssey: e.g., one can find a singular misunderstanding, when Odysseus is jealous of a young man who embraces Penelope, but he is Telemachus (Meier 1886: 26). By considering that the same misunderstanding is found in a traditional Kurdish tale (Zanà 1992: 166), one can infer that it might go back to an old independent tradition, previous to the Indo-European diaspora.

\section{Problems of Homer's Geography in the Mediterranean}

Homeric geography gives rise to innumerable problems: the archipelago of Ithaca does not fit the Ionian Island at all; "Even the topographical detail of Odysseus' home island of Ithaca can be shown to be in a jumble, with several points appropriate to the neighbouring isle of Leucas but quite impossible for Ithaca" (Finley 1979: 33); Telemachus' voyage from Ithaca to Pylos is too short (Od. II: 434); his swift journey by chariot from Pylos to Lacedaemon, along "a wheat-producing plain" (Od. III: 495) is too easy; the river Alpheus "flows broad over the Pylian country" (Il. V: 545); Agamemnon's course from Troy to Mycenae rounding Cape Malea (Od. IV: 514) is incomprehensible; the very long days in the land of the Laestrigonians are freakish; the Hellespont is always considered "wide" (e.g., Il. VII: 86) or even boundless (XXIV: 545); the allies of the Trojans, such the Lycians and the Cilicians, whom Hector considers his neighbours (Il. XVII: 220), instead lived far away (Nilsson 1932: 57); Calydon is regarded as a "pleasant city" (Il. IX: 531), which "clashes with its mountain position" (Graf 1997: 50), not to mention the ancient questions of Pylos's (Graf 1997: 50) and Pharos's position, as well as the absurd border between Argolis and Pylos along the sea (Il. IX: 291-295).

Besides, as regards Odysseus' wanderings, Strabo claims: "It is evident that all these things are clearly imagined in the Atlantic ocean" (Geography 1.2.18), which fits what Plutarch says about Ogygia and the stream reversal of the river of Scherie (Od. V: 451-453). And what of the regions of the mountainous Peloponnese, that look like a plain in both poems? 
At this point, the original Nordic location of the oral sagas that gave rise to the two poems can explain all problems - geographic, climatic and so on - as well as the huge anomaly of the great battle that takes up the central books of the Iliad, a battle that continues for two days and one night. It is incomprehensible that the darkness of night in the Mediterranean world would not put a temporary stop to the fighting, but the fact that the conflict continues unabated through these hours makes a good deal of sense in a Northern setting: what allows Patroclus's fresh troops to carry on fighting through the night without a break is the dim, residual night light that is typical at high latitudes around the summer solstice. The Iliad even records the name of this phenomenon: "When it was still clear-around [amphilykē] night, before dawn broke..." (II. VII: 433). The Homeric term amphilykē, which refers to a phenomenon unknown in the Mediterranean area, is very uncommon in Greek literature, where it is only found in the Argonautics by Apollonius Rodius, right in the passage that mentions the Hyperborean Apollo (Arg. II: 671). Besides, this interpretation allows us to reconstruct the stages of the entire battle in a coherent manner (while they become a hodgepodge if the battle is compressed in a single day).

It is also noteworthy that two days after the clear night of June, that had allowed warriors to fight until the day after, there is the overflowing of the two rivers of Troy: "the whole plain had been flooded" (Il. XXI: 300). Actually, the overflowings of the Northern rivers usually occur in June, owing to the spring thaw; they coincide, therefore, with the clear nights, which confirms the trustworthiness of the Iliad.

All of this is a piece of evidence of a Northern set, which squares with a passage of the Iliad: "When the cries of the cranes fleeing from winter and incessant rain come to heaven..." (Il. III: 3-4). This naturalistic painting hides another piece of evidence of the northern location of Troy: "This behavior is typical of a flight of cranes that leave northern Europe in autumn, whereas these birds migrate from South in spring" (Tripodi 2013: 263). On the contrary, a Mediterranean poet would have spoken of "cranes fleeing from summer", instead of "from winter". In short, Homer describes a Northern scene here.

\section{The Reconstruction of the Homeric World}

\section{Ogygia, Scherie and Ithaca}

The key that allows the reconstruction of Homer's original world is provided by a passage by Plutarch, which states that Calypso's island Ogygia lies in the North Atlantic, "five days of navigation from Britain, towards the sunset" (De Facie quae in orbe lunae apparet 941a). Ogygia can be identified with one of the Faroe Islands, Nolsoy, where, according to the Odyssey, there are caves, meadows, large colonies of seabirds, small watercourses, a mountain called Høgoyggj, and low beaches that allow an easy landing. Besides, the position of Nolsoy along the Eastern side of the Faroe archipelago, before the 
Norwegian coast, tallies with the arrival of a ship coming from Charybdis (the Maelstrom area in the Lofoten Islands), and the sailing towards Scheria (in Southern Norway). So, there are good reasons to suppose that Homer's and Plutarch's Ogygia might be one of the Faroes.

By sailing from Ogygia in an easterly direction (Od. V: 276-277), one can locate Scherie, the land of the Phaeacians, on the southern coast of Norway near the mouth of the river Figgjo, where there are many Bronze Age remains: i.e., graves and rock carvings that often portray ships. Homer calls the Phaeacians "renowned navigators" (Od. VIII: 191), although they are unknown in the Mediterranean world. It is noteworthy that in the ancient Nordic language, skerja means "rock," which squares with the features of that sea: "only sheer cliffs, rocks and reefs" (Od. V: 405); moreover, Odysseus in his landing on the mouth of the river took advantage of the reversal of the stream, due to the high tide.

From Scherie the Phaeacians took Odysseus to Ithaca, which Homer talks about in great detail: it is the westernmost island of an archipelago where there are three main islands: Dulichium (i.e. "the Long" in Greek, never found in the Mediterranean), Same and Zacynthus (Od. IX: 24).

A group of Danish islands in the Baltic Sea, i.e., the South-Fyn Archipelago, is the only one in the world that fits with Homer's descriptions. It includes three main islands: Langeland, the "Long Island", that is Dulichium, Aerø, that fits Homeric Same, and Tåsinge, ancient Zacynthus. Amongst this archipelago one can also identify Asteris, the little island "in the strait between Ithaca and Same" (Od. IV: 845), where Penelope's suitors tried to waylay Telemachus' ship, which was coming back from Pylos: it is today's Avernakø.

This identification is strengthened by a comparison between the numbers of Penelope's suitors - fifty-two coming from Dulichium, twenty-four from Same, and twenty from Zacynthus (Od. XVI: 247-250) - and the surfaces of the respective islands: Langeland (Dulichium), $185 \mathrm{~km}^{2}$; Aerø (Same), $88 \mathrm{~km}^{2}$; Tåsinge (Zacynthus), $70 \mathrm{~km}^{2}$. The almost perfect proportion between the triplets (52-24-20) and (185-88-70) is astonishing.

The last island in the archipelago, located westwards, "facing the night" (Od. IX: 26), is Odysseus' Ithaca, now known as Lyø: it closely coincides with the indications of the poet, not only in its position, but also in its topographical and morphological features (e.g., one can find the ancient "Harbour of Phorcys", the "Crow Rock", a Neolithic dolmen, and so on). 
Figure 1. Lyø, Homer's Ithaca

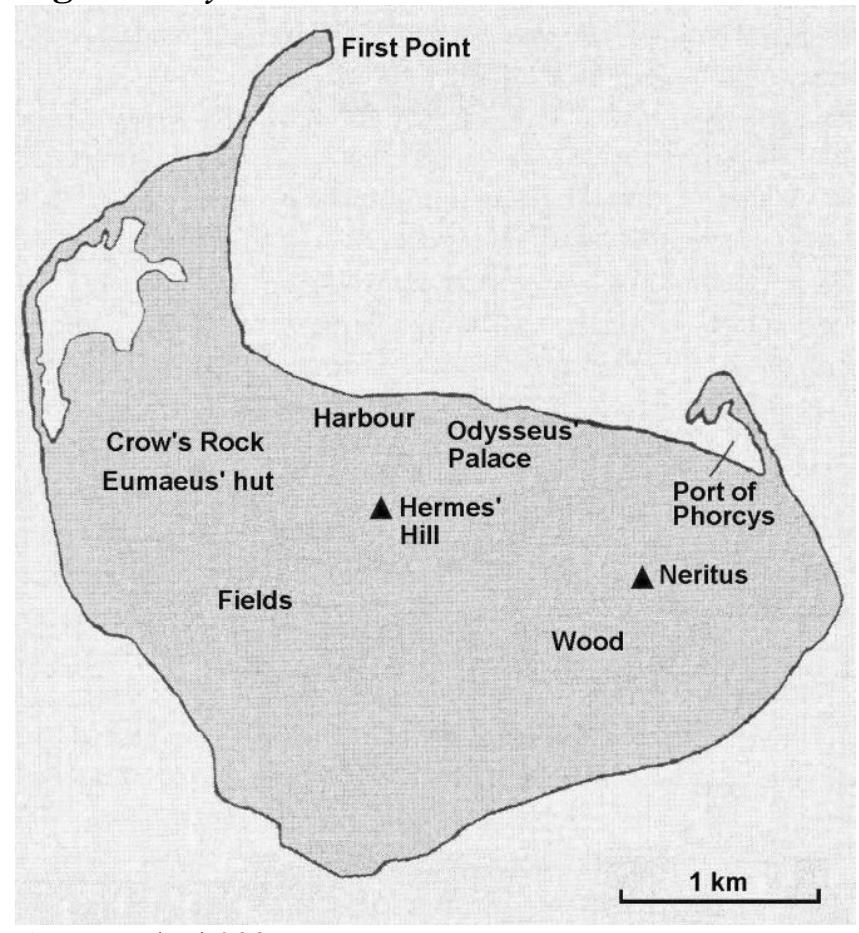

Source: Vinci 2006.

In front of Dulichium lay Elis (Il. II: 626), one of the regions of Peloponnese. Elis is identifiable with the southwestern side, facing Langeland, of the large Danish island of Sjaelland: here is the original "Island of Pelops", in the real meaning of the word "island" (nēsos). On the other hand, the Greek Peloponnese (which lies in a similar position in the Aegean Sea, i.e., on its southwestern side) is not an island, despite its name. It is remarkable that Telemachus' swift journey by chariot from Pylos to Lacedaemon, along "a wheat-producing plain" (Od. III: 495), as well as the war between Pylians and Epeans narrated in Book XI of the Iliad, which have always been considered inconsistent with Greece's uneven geography, perfectly fit the flat island of Sjaelland, where the Atreidae and king Nestor reigned. All geographic incongruities arising in the Greek world, such as the absurd border between Argolis and Pylos along the sea (Il. IX: 291-295), disappear here (Vinci 2006: 242).

Troy

Our search now turns to the area of Troy, where, as Moses Finley claims, "Not a single scrap links the destruction of Troy VIIa with Mycenaean Greece, or with an invasion from any other source. Nor does anything known from the archaeology of Greece and Asia Minor or from the Linear B tablets fit with the Homeric tale of a great coalition sailing against Troy from Greece (...) nor is a Trojan War" ( Finley 1979: 43). Besides, Dieter Hertel (who worked on the site of Hisarlik), claims that both Wilusa and the city found by Schliemann have 
nothing to do with the Homeric Troy: "Troy/Filium was not Wilusa (...) As to the supposed relationship between Wilusas's King Alaksandus and Paris Alexandrus, Priam's son, "King Alaksandus's father was not called Priam but Kukunni" (Hertel 2003: 55) (moreover, Paris never was king of Troy). It should also be considered that "thanks a series of core samples taken in 1977 we now know that in prehistoric times the plain was covered by an extensive arm of the sea, which reached up to Hisarlik in the Troy VI period (...) and the findings of Schliemann, Virchow and Burnouf, based as they were on inadequate samples, were in error" (Traill 1995: 190). Besides, Homer mentions the point "where the Simoïs river and the Scamander mix their waters" (Il. V: 774), which is impossible in the area of Hisarlik, where the two rivers don't mix at all.

The Homeric Troy stood close to the "broad Hellespont" (e.g. Il. VII: 86, XVII: 432), very different from the Dardanelles. Saxo Grammaticus often mentions a people named "Hellespontins", sworn enemy of the Danes, and a "Hellespont" (Gesta Danorum IX, IV: 20) in the Eastern Baltic area; by considering that the Nordic counterpart of the narrow Mediterranean Hellespont is the broad Gulf of Finland, it is noteworthy that in an area facing the Gulf of Finland, west of Helsinki, there are many place-names that startlingly recall those of the Iliad, and in particular the Trojan Allies: Askainen, Reso, Karjaa, Nästi, Lyökki, Tenala, Kiila, Kiikoinen, and many others. Moreover the place-names Tanttala and Sipilä (the mythical King Tantalus, whose kingdom lay near the area of Troy, was buried on a mountain named Sipylus) indicate that this theme not only touches on Homer's geography, but affects the entire world of "Greek" mythology.

And Troy? Right at the centre of this region, $100 \mathrm{~km}$ west of Helsinki, there is a village, Toija, whose characteristics correspond exactly to those Homer passed down to us: a hilly ground dominating the valley with the two rivers, a plain stretching to the coast, and a mountainous area (i.e. Ida, which never appears to be a mountain in the Iliad) on its back. This area reveals significant traces of the Bronze Age: near Toija there are there are lots of Bronze Age tumuli, like the ones described in the Iliad (VII: 86). Besides, the old copper mines of Orijärvi, $8 \mathrm{~km}$ east of Toija, clarify the probable origin of Priam's wealth, often mentioned in the Iliad.

As to the Trojan wall, the poet considers the Trojan wall to be inferior to the Achaean wall (Il. VII: 452), which itself is rather like a sturdy fence, given that its stone-and-wood structure (XII: 29, 36) is brought down by the first attack of the Trojans. So, it was archaic like that of the Phaeacians, "assembled with pales" (Od. VII: 45), which may sound rather primitive, but Homer says: "It's wonderful to look at!" (Od. VII: 45). Actually, "earlier fortifications in barbarian Europe seem in the main to have been simple palisades, or earthwork banks and ditches, set around a village" (Piggott 1968: 202).

In ancient days Toija was much closer to the sea, but after the end of the ice age, the land of Finland began to rise. Over the thousands of years that have elapsed since Homer's time, the distance between Toija and the coastline has gradually increased (the speed of raising is about $4 \mathrm{~mm} /$ year now). However, the location of the ancient "beach" where the Achaeans landed and camped, 
called aigialos by Homer (Il. XIV: 34), is still marked by a place called Aijala, about $7 \mathrm{~km}$ southwest of Toija, towards the sea.

As regards Aeneas, who, according to Virgil, reached Italy after the Trojan War, according to Homer he was destined to be Priam's successor: "Aeneas's power will reign over the Trojans and the sons of his sons and the ones who will come after" (Il. XX: 307-308). This idea is also found in the Homeric Hymn to Aphrodite 196-198), whose formula inheritance is very close to that of the poems" (Montanari 1992: 49).

\section{The Whole Homeric World}

After finding Ithaca and Troy, the "Catalogue of Ships" in the second book of the Iliad allows us to reconstruct the whole world of Homer - i.e., the unknown world of the Nordic Bronze Age - by following step by step the coasts of the Baltic Sea anticlockwise.

E.g., the Swedish bay of Norrtälje, whence the ferries leave for Helsinki now, coincides with Aulis, from which the Achaeans left for Troy; in the Aland archipelago, the island Lemland recalls the ancient Lemnos, where the Achaeans halted during the voyage; near Stockholm one comes across Oedipus's Thebes; the Öland island is the ancient Euboea; the primordial Athens of Theseus, of which a singular description is left by Plato in the dialogue Critias (the town lay on a wavy plain with many rivers) should be located near Karlskrona, a modern Swedish city. Then the Catalogue mentions the Achaean kingdoms (Argolis, Lacedaemon, Pylos, Arcadia and Elis) of the flat Peloponnese, Dulichium and Ithaca's archipelago.

So, the Iliad confirms the previous identification with Sjælland, Langeland and Lyø. The "spacious land" of Crete, which Homer never identifies as an island, lay along the Polish coast of the Baltic; it has nothing to do with the Mediterranean island (though Crete plays a very significant role in Greek mythology, "there is nothing in Minoan-Crete art which seems to illustrate any type of known legend") (Vidal-Naquet 1991: XX). 
Figure 2. Homer's World in the Baltic by following the Catalogue of Ships



Source: Vinci 2006.

Then the Catalogue heads for the regions of Eastern Baltic, where Hellas lay in today's Esthonia, facing the Hellespont (instead the natural contiguity of Hellas with the Hellespont was not maintained in the Greek world). Phthia, Achilles' homeland, lay on the fertile hills of southeastern Esthonia, along the border with Latvia and Russia, stretching as far as the Russian river Velikaja and the Lake Pskov. Myrmidons and Phthians lived there, ruled by Achilles and Protesilaus respectively. Next, the sequence reaches the Finnish coast, facing the Gulf of Bothnia, where the village of Jolkka lies, which reminds us of Iolcus, Jason's mythical city. Farther north, one can identify Mount Pelion the region of the Lapithae and the Centaurs - as well as the location of Pieria, north of the Arctic Circle, that is confirmed by an apparent astronomical anomaly, linked to the Moon cycle (Humbert 1967: 108), which is found in the Homeric Hymn to Hermes, that can only be explained by the high latitude (Vinci 2006: 287-288.). 
The case of Sidon confirms this reconstruction. Actually, according to the Iliad, Sidon lay on the course between Troy and Sparta - as it results from a passage referring to Paris' voyage with Helen (II, VI: 289-292), which is corroborated by Menelaus' way back (Od. XV: 118) - but in the Mediterranean set, Sidon lies very far from both Troy and Sparta, or rather, more than $700 \mathrm{~km}$ far from the Aegean Sea! Instead in the Baltic set, since Troy and Sparta prove to be in southern Finland and in the south-east side of Sjaelland respectively, it follows that the Sidonians, the "great craftsmen" (II, XXIII: 743), probably lived on the coast of Sweden, which is confirmed by Tacitus: "The tribes of the Sitones are followed by the Suiones" (Germania 45: 6), where the Suiones are today's Swedes.

\section{Odysseus's Wanderings}

After the Trojan War, a storm deviates Odysseus from the return route, then he is involved in many adventures: his wanderings are set in North Atlantic, until he finally reaches Ogygia. In fact, a map by Adam of Bremen, dating back to the $11^{\text {th }}$ century, shows that the Cyclopes lived along the coast of Northern Norway, where there is also a "Cyclopes' island" (Insula Cyclopum) (Bjørnbo 1912: 70).

Besides, this map places the Terra Feminarum on the Baltic shores, where, according to Adam of Bremen, "there are the Amazons" (Gesta Hammaburgensis Ecclesiae Pontificum IV: 19). This tallies with the fact that, according to the Iliad, the Amazons lived in the Baltic area and had fought with king Priam before the Trojan War (Il. III: 189).

Moreover, Saxo Grammaticus claims that they lived in Demmark in ancient times (Gesta Danorum VII, VI: 8). The Cyclopes, therefore, lived along the coast of Norway (they might be compared to the Trolls of Norwegian folklore).

The map also shows that the Cyclops lived in the region of the Riphean Mountains. Adam also says: "The Riphean Mountains (...) where the Cyclopes live, who have only one eye in the middle of the forehead" (Gesta Hammaburgensis IV: 25), which fits the fact that the Cyclopes lived "at the top of high mountains" (Od IX: 113).

So, the mythical Riphean Mountains, which the ancient geographers vaguely placed towards the north, are the mountains of central and northern Norway. One might also wonder whether the name "Riphean" (or "Ripean") derives by metathesis from the name of Hypereie, the "high land" that the Phaeacians had shared with the Cyclopes (Od. VI: 4-5) before settling in the Scheria. 
Figure 3. The Map by Adam of Bremen

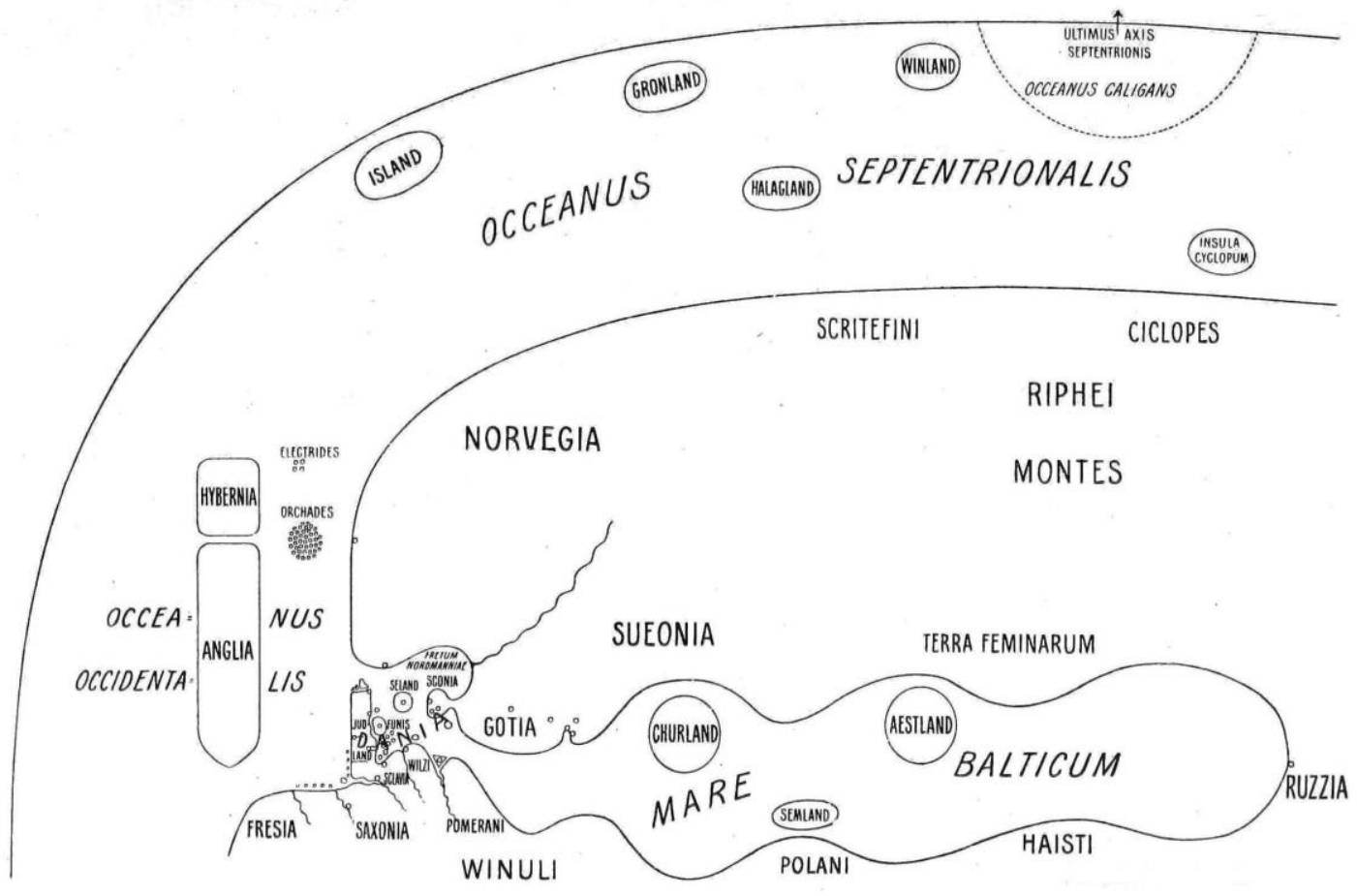

Source: Bjørnbo 2012.

After the Cyclopes, Odysseus reached the land of the Laestrygonians, where there are very long days, caused by the high latitude. As to the island of Circe, "the one with many drugs" (polypharmakos; Od. X: 276: she was, therefore, a typical Lappish shaman, experienced in psychotropic potions), it lay north of the Lofoten. Actually, in Aeaea there are typical Arctic phenomena such as the midnight sun (Od. X: 190-192) and the dancing of the dawn (XII: 4).

The Sirens are very dangerous shoals for sailors, who are attracted by the enticing noise of the backwash (the "Sirens' song") and deceive themselves that landing is at hand, instead, if they get near, are bound to shipwreck on the reefs. This is the typical mechanism of a kind of metaphor known as kenning, a poetic device commonly used in Norse poetry and also in Homer's works: the expression "sea horses" (Od. IV: 780) used by Penelope to indicate ships, is identical to the Norse vágmarr, "horse of the waves" (probably also the famous "wooden horse" is a kenning indicating a ship).

The description of Charybdis fits the features of the Maelstrom, the notorious whirlpool, near the Lofoten Islands, described in the novel A descent into the Maelstrom by E.A. Poe. In that area the great cave called Kollhellaren and the three-tipped island of Mosken fit perfectly the cave of Scylla and the island Thrinacia, which means "trident", respectively. The Lord of Thrinacia is the Hyperion Sun, where hyperiōn means "going over": given the location of Thrinacia above the Artic Circle, this refers to the phenomenon of the midnight sun, which moves always above the horizon during the Arctic summer. Then Odysseus reaches Ogygia in the Faroe Islands, before the Norwegian coast. 
These adventures, presumably taken from tales of ancient seamen and elaborated again by the Poet's fantasy, represent the last memory of oceanic routes followed by the ancient navigators of the Nordic Bronze Age when the climate was milder than now; eventually their identification became blurred because of their transposition into a totally different Mediterranean context.

\section{The Nordic Origin of the Mycenaean Civilisation}

\section{Pieces of Evidence in Greece}

There are many archaeological pieces of evidence found in Greece about the Nordic origin of the Mycenaean civilisation: ${ }^{2}$ "A very important discovery was made in a chamber tomb at Dendra (...) Two stone slabs were found there (...) Their similarity with the menhirs, known from the Bronze Age of Central Europe, is striking (...) If this is so, it is a very striking corroboration of the Nordic origin of the Mycenaeans" (Nilsson 1933: 80-81). Besides, "Amber is found frequently and in great quantities in many Mycenaean tombs of the mainland, e.g., in the earliest shaft graves at Mycenae (...) It is especially found in earlier Mycenaean tombs, while it is scarce or altogether absent in later tombs. The extreme scarceness of amber in Crete is in striking contrast to the abundant finds on the mainland (...) There is only one explanation of the difference, viz., that a people immigrating from the north brought the taste for and the use of amber with it" (Nilsson 1933: 76). Actually, "amber from the Baltic first makes its appearance in the Aegean around the time of the shaft graves of Mycenae" (Renfrew 1990: 219).

What we said about amber, plentiful "in earlier Mycenaean tombs, while it is scarce or altogether absent in later tombs", can be extended to the swords: "In the tombs of Mycenae of the seventeenth and sixteenth centuries BC, during the period of formation of the Mycenaean kingdoms, all warriors were buried with a large number of swords, on average about ten per person. On the contrary, in the following centuries only a few warriors were buried with a sword, and never more than one (...) Eva Hjärtner Holdar emphasizes that the number of bronzes suddenly increases dramatically in Scandinavia in the seventeenth century BC (...) Should we think that the swords were introduced into Scandinavian Europe and from there they spread to other European regions? According to the data of Eva Hjärtner Holdar, it seems so" (GiumliaMair 2013: 328.)

This tallies with the bronze swords, similar to Mycenaean swords, found in Germany near the village of Nebra (50 km west of Leipzig), together with a bronze disk of around $30 \mathrm{~cm}$ diameter, inlaid with gold symbols, i.e., a sun or full moon, a lunar crescent, and stars, including a cluster interpreted as the Pleiades. "The disk has been dated to 1600 BC" (Pásztor 2015: 1350). What is portrayed on the Nebra disk is very similar to the subject depicted in the central layer of Achilles's shield (Il. XVIII: 483-487): the sky with the sun, the moon

\footnotetext{
${ }^{2}$ Cf. Nilsson 1933, pp. 71-86.
} 
and the stars, where the Pleiades are also mentioned. All of this forms an amazing "triangle" among the Nordic world, the Homeric world and the Mycenaean world.

Besides the association of Baltic amber and swords, there is further evidence of the Nordic origin of the Mycenaeans: "The Mycenaean palaces recall the cold and damp northern countries from which they had undoubtedly come (...) They are very different from the typically Mediterranean architectural conception of the buildings of Crete" (Lévèque 1970: 47) Moreover, the structure of the megaron, the main hall of the Mycenaean buildings, "is identical with the hall of the old Scandinavian kings" (Nilsson 1933: 75).

The migration of the Mycenaeans from the north is further corroborated by their physical features: "The Indo-Europeans who settled in Greece must have been tall and blond, just like Homer's well-built blond heroes" (Giannelli 1983: 52) The remains found in Mycenaean graves suggest men who had the "physique of a champion" (Edwards 1973: 438) and anthropological studies of human remains found in Kalkani's Mycenaean necropolis make it clear "that it would be possible to refer the skulls of the women to the Mediterranean type, but that the skulls of the men have a larger capacity than is usual there, and that no objection can be made if they are thought to belong to Nordic men. The same difference is observed between the king and queen from Dendra (...) In the Mycenaean Age, the dominating people had northern connections" (Nilsson 1933: 85).

Besides, Geoffrey Bibby underlines "the common origin of the Achaean princes of Greece and Asia Minor in the fifteenth century BC and the sunworshipping farmers of Scandinavia," (Bibby 1966: 190) and, in his turn, Bertrand Russell claims: "There are traces which most probably confirm that they were Greek-speaking conquerors, and that at least the aristocracy was made up of blond Nordic invaders who brought the Greek language with them" (Russell 1991: 29).

\section{The Nordic Bronze Age and "The Collapse of the Traditional Framework"}

If Mycenaean archaeology has brought this evidence of their Northern origins to light, on the other hand Nordic archaeology shows strict correlations between the Scandinavian Bronze Age and the coeval Aegean civilizations. A remarkable example is the extraordinary tomb found near Kivik in southern Sweden that consists of a large circular stone tumulus, no less than 75 meters in diameter, known as "Bredarör." It contains a sarcophagus, which is about four meters long, built of square stone slabs engraved with stylized figures of humans beings, animals and objects such as axes and wheels.

Archaeologists recognize the similarity between these figures and the Bronze Age finds in both Aegean and Near East areas: Klavs Randsborg, after analyzing the figures engraved on the tomb slabs, compares them with the pictures of a sarcophagus from Hagia Triada in Crete and the stelae of the shaft-graves from Mycenae. ${ }^{3}$ Actually, there are puzzling similarities between

\footnotetext{
${ }^{3}$ Cf. Randsborg 1993.
} 
this Scandinavian tomb and the Aegean Bronze Age finds, which have already bewildered scholars in the past; so much so that, in the $19^{\text {th }}$ century one of them even attributed the construction of the tomb to the Phoenicians (Randsborg 1993: 114). Randsborg deals with these parallels with due caution: "All other allusions are left to the reader" (Randsborg 1993: 2). His prudence is quite understandable because the parallels between such a macroscopic phenomenon like Kivik's tomb and the coeval Mediterranean civilizations are inexplicable, unless one admits that the Mycenaeans came from the north, as Martin Nilsson and Bertrand Russell openly declare.

Rupestrian carvings like those found on Kivik's tomb are typical of the Nordic Bronze Age. They focus "on three main topics, i.e., ships and shipping, agriculture and livestock, and weapons and duels" (Bibby 1960: 279) all of which being typical also of the Homeric world. Besides, "feuds, raiding and piracy were regular occurrences in the lives of the Nordic people," (Melheim 2014: 2) as they were in Homer. Moreover, "The variety of Germanic bronze objects was amazing: there were precious swords, valued ornaments, goldplated cult discs, clips, buckles, helmets, shields, chokers and even shaving, ear and manicure sets (...) 1500 years before the arrival of the Romans in the Nordic territories, there were already such very high standards of living and civilization, that they can only be compared to the Greek civilization of the same period" (Fischer-Fabian 1985: 90).

Swedish archaologists have recently found a big, skilfully planned city, extending on more than $1 \mathrm{~km}^{2}$, in the site of Bjästamon, outside Härnösand in the north of Sweden, that dates back to the $3^{\text {rd }}$ millennium BC. "From the findings it appears that this city, dated around 2,800 $\mathrm{BC}$ and huge for that period, was in contact and exchanged goods with the territories of Russia, Karelia, Poland, Germany and Denmark (...) the distribution map of copper mines in Sweden shows that the largest and most important are located around Bjästamon. Thus it is possible that the reason for the wealth of the city was copper, easily accessible and removable even at these latitudes during a period in which climate was mild" (Giumlia-Mair 2013: 326).

This also squares with the fact that radiocarbon dating, corrected with dendrochronology (i.e., tree-ring calibration), recently questioned the dogma of the Eastern origin of European civilization. Colin Renfrew describes the consequences for traditional chronology: "These changes bring with them a whole series of alarming reversals in chronological relationships. The megalithic tombs of western Europe now become older than the Pyramids or the round tombs of Crete, their supposed predecessors. The early metal-using cultures of the Balkans antedate Troy and the early Bronze Age Aegean, from which they were supposedly derived. And in Britain, the final structure of Stonehenge, once thought to be the inspiration of Mycenaean architectural expertise, was complete well before the Mycenaean civilization began" Renfrew 1990: 76). Consequently, in a chapter which is significantly entitled "The Collapse of the Traditional Framework", Renfrew goes so far as to say: "The whole carefully constructed edifice comes crashing down, and the storyline of the standard textbooks must be discarded" (Renfrew 1990: 115). 
His conclusion is shocking: "The conventional chronological links are snapped; and the east Mediterranean innovations, which were supposedly carried to Europe by diffusion, are now found earlier in Europe than in the east. The whole diffusionist framework collapses, and with it the assumptions which sustained prehistoric archaeology for nearly a century. These are the consequences of what may justifiably be called the second radiocarbon revolution" (Renfrew 1990: 94).

One should also note that graffiti of a "Mycenaean" dagger was found on one of the sarsen monoliths of Stonehenge in 1953; other traces in the same area appear to precede the rising of this civilisation in Greece.

The Nordic origin of the Mycenaeans can also explain the positive attitude of the ancient Greeks - who usually looked down on the "barbarians" towards the Hyperboreans, the mythical inhabitants of the north: Diodorus Siculus, in a passage upon Apollo's cult, states that the Delphians and the Hyperboreans were "on very friendly terms", and that "they had inherited this tradition of friendship from ancient times" (Bibliotheca Historica, II: 47). A similar idea had been expressed by Herodotus many years before: "For those Hyperborean maidens who died in Delos, the girls and the boys of the Delians cut off their hair" (Histories IV: 34).

The Hyperboreans were linked with Apollo: Pindar calls them "Apollo's people, the Hyperboreans" (Olympian 3: 16). As for that god, a very interesting case "is the famous solar chariot found in a swamp at Trundholm (Denmark). It seems to materialize a myth identical to the Greek myth of Apollo. The sun, in its chariot drawn by a horse, arises at the dawn from the primordial waters, crosses the sky, then at twilight it dives again these waters, from which it will emerge purified and regenerated" (Otte 2008: 183).

On the other hand, "Climatologists generally agree that four and a half millennia ago our planet was four degrees Celsius warmer and that in Scandinavia there was the so-called Post-Glacial Climatic Optimum. The climate change began in circa $2700 \mathrm{BC}$. The warm climate, comparable to that of present-day Mediterranean, permitted a relatively dense population and good farming, with even grapes being grown in Scandinavia at this time. The Nordic Bronze Age was then characterized by a warm climate and the mines were, most probably, much more accessible than they are now. Jean-François Maréchal, in a study on Scandinavian prehistoric mining and metallurgy, lists a large number of copper mines which might have been exploited at the time, and goes so far as to suggest that Scandinavia might even have been the cradle of European metallurgy (...) The idea that local extractive metellurgy might have existed already at an early stage is certainly accettable, and the rich production of heavy and elaborate metal objects in the Bronze Age may confirm this theory" (Giumlia-Mair 2009: 130-131).

\section{The Migration of the Achaeans}

What induced the Achaeans to move towards the Mediterranean Sea? Probably the consequences of the catastrophic explosion of Thera (about 1620 
BC), whose effects were felt across the world, to the point that some scholars have even linked them to the history of China. ${ }^{4}$ The Achaeans probably followed the Dnieper River down to the Black Sea, as the Varangians (Swedish Vikings, whose culture is, in many ways, similar to that of the Achaeans) did in the $9^{\text {th }}$ century AC to found the kingdom of Rus' (afterwards, many of them served in the Byzantine Army, constituting the elite Varangian Guard). Actually, Mycenaean shaft graves recall the contemporary graves of the lower reaches of the Dnieper, where "again a curious burial posture with outbent knees is found, as at Mycenae" (Piggott 1968: 123).

The migrants took the place-names of their lost Nordic homeland along with them to the places where they eventually settled (as it happened when the Europeans colonized America), and through many generations they preserved the memory of the heroic age and the feats performed by their ancestors in their lost homeland.

However, the memory of the migration from the North faded after the fall of the Mycenaean world at the hands of the Dorians (12 ${ }^{\text {th }}$ century BC). This way the ancient oral tales, dating back to the distant Scandinavian past, were crystallized as "myths" detached from any temporal and geographic reality. Many years after, around the $8^{\text {th }}$ Century BC, this oral tradition was put in writing: here is the origin of the Homeric poems and the rest of Greek mythology.

Incidentally, "a curious circumstance regarding Homer is his appearance in the scene just at the end of the oral period, when writing, thanks to the introduction of a practical alphabetic system from the East, in the ninth or at the beginning of the eighth century BC, began to spread in the Greek land" (Kirk 1989: 82). However, we believe that this coincidence was not pure chance at all: the oral epic songs that gave rise to the Homeric poems probably were put in writing as soon as the new writing system became available.

The analogy with the Varangians can help to solve another problem: is it possible to identify, among the Achaean peoples mentioned by Homer, the ones who were the founders of the Mycenaean world, which in turn was at the origin of Greek civilization? To answer this question, we must first consider that the Varangians were the Swedish branch of the Scandinavian Vikings, whose expansion lines pointed to the east, while the Norse and the Danes pointed to the west and the south respectively. Geography, therefore, suggested the displacements of populations in the Middle Ages. It is reasonable to believe that the same situation had already occurred in the Bronze Age. Actually, as one can infer from the reconstruction of the Homeric world, the Ionians (i.e., the Homeric Iaones) lived in southern Svealand, i.e. the Swedish region that takes its name from the Suiones mentioned by Tacitus (Germania 45, 6). This name, Suiones, is linguistically equivalent to that of the Homeric Ionians as it is demonstrated by Arduino Maiuri. ${ }^{5}$ So it is likely that the Achaeans who migrated to the Aegean Sea to found the Mycenaean civilization - whose

\footnotetext{
${ }^{4}$ Cf. Foster 1996.

${ }^{5}$ Private communication by Arduino Maiuri, who has prepared a paper on this topic for the panel of ATINER upon "The Nordic origins of the Homeric Poems" (Athens, April 10, 2017).
} 
language was an Ionian dialect, which is similar to that of Homer for more were Ionians come from Sweden.

One must also consider that another Ionian dialect is that of classical Athens, Plato's city, he who has bequeathed to us the description of its primordial Swedish counterpart, which lay in the region of modern Karlskrona, very different from Greek Attica; besides, also "the part where there is the Acropolis was very different from today's" (Critias 111e). This clarifies why the name of Athens is plural: according to the typical morphology of many Baltic coasts, the primitive location of the city was fragmented among various islands and peninsulas (this is confirmed by another example from the classical world, i.e. the Latin plural form of the name Syracuse in Sicily, deriving from the peculiar topography of that city, spanning the mainland and the facing island). This also explains why the name of Boeotian Thebes occurs in the plural: its Baltic precursor lay not very far from the islands where Stockholm stands today. On the other hand, the volutes of the Ionic capitals - let us think of the Erechtheum on the Acropolis of Athens - are spirals, i.e., a very common decoration of the Nordic Bronze Age.

\section{Conclusions}

The Nordic setting for the epics solves many problems of the Homeric narrative. Lots of references in the poems clearly speak of typically northern phenomena, such as the clear nights (in the longest battle of the Iliad and in the land of the Laestrygonians); the midnight sun (in Circe's island and Thrinacia); the Dawn's dances (in Circe's island); the darkness of the winter solstice (in the land of the Cimmerians and in the Homeric Hymn to Hermes); the aurora borealis (cf. Il. XVII, 547); the anomalies in the phases of the Moon (in the Homeric Hymn to Hermes), and so on.

It is noteworthy that the two poems relate to territories quite far afield. The Odyssey indicates the position of Scheria, Ithaca and the kingdoms of Peloponnese, and through Odysseus' wanderings gives us a consistent picture of the Atlantic coast of Norway and the facing islands. The Iliad enables us to reconstruct the Trojan area and the Achaean settlements along the Baltic in the Early Bronze Age. In short, the geographic information extracted from the entire Homeric universe finds its natural location in four main "clusters", i.e., the Ithacan world in the Danish islands; the world of Troy in southern Finland; the Achaean world along the Baltic coasts; Odysseus' adventures in the North Atlantic Ocean.

Each of these clusters closely squares in geography, morphology, climate and toponomy to the corresponding regions found in the Nordic world, also considering the inconsistencies of the traditional Mediterranean location, on which Claudio Cerreti claims: "The Mediterranean setting of the Homeric poems is not a scientific verity, but simply a tradition, which always resulted in endless demonstration problems. But this tradition is deep-rooted and almost 
ingrained in our culture, to such an extent that it represents the only but formidable resistance against every divergent hypothesis" (Cerreti 2000: 320).

What of archaeology? Besides the fact that, as leading scholars indicate, the Nordic origin of the Mycenaeans is based on archaeological evidence found on Greek soil, one should also consider: the similarities, dating back to the Bronze Age, between Nordic and Aegean artifacts; the Bronze Age tumuli and rock carvings portraying ships that have been found exactly where the Phaeacian seafarers were settled, as determined by following Homer to the letter; the analogies between significant Scandinavian Bronze Age remains (such as at Kivik) and coeval Aegean ones; the traces the Mycenaeans left in Wessex (England) at least many years before they settled in Greece; the Nebra disk with two "Mycenaean" swords. Besides, the site of Bjästamon in Sweden shows the existence of a developed urban civilisation in the North of Europe, dating back to the third millennium BC. All of this fit the backdating of the Nordic Bronze Age and "the collapse of the traditional framework," as Colin Renfrew claims.

However, this research is still open. It requires further archaeological confirmations, after which an immense amount of investigations in many fields, directly or indirectly related to this theory, awaits the experts, as it is normal in the scientific world when there is a so sweeping paradigm shift. The relationship between the world of the Nordic Bronze Age and the Swedish Mediterranean Ionia (which was the basis of the Greek civilization: we must only think of Herodotus, born in Ionia) appears to be extremely intriguing and open to many, huge developments concerning the dawn of the Greek civilization, also considering that it dates back a thousand years the history of Europe.

This interpretative proposal opens new, fascinating horizons upon the origin and prehistory of the whole European civilization, shedding light on the peoples of the Nordic Early Bronze Age and illuminating their life, culture, religion and history, which have been almost totally unknown till now, given the lack of a Nordic literature dating back to that period. With Homer as our lodestar, we are able to develop a new understanding of our European common origin.

\section{References}

Apollonius Rhodius (1998) Argonautiche. Milano: Rizzoli.

Bendelli G (2013) Odysseus Hibernatus. In Rivista di Cultura Classica e Medioevale 2(2013). Pisa.

Bibby G (1960) Le navi dei Vichinghi [The Viking Ships]. Torino: Einaudi.

Bibby G (1966) Quattromila anni fa [Four thousand years ago]. Einaudi, Torino.

Bjørnbo AA (1912) Cartographia Groenlandica [Cartographia Groenlandica]. Meddelelser om Grønland 48. Reitzel: København.

Canali L (Ed) (1991) Tacito. La Germania [Tacit. Germany]. Pordenone: Studio Tesi.

Càssola F (Ed) (1994) Inni Omerici [Homeric hymns]. Mondadori. 
Cerreti C (2000) Recensioni e appunti bibliografici e cartografici [Reviews and bibliographical and cartographic notes]. In Bollettino della Società Geografica Italiana. Roma: Gennaio-Giugno.

Cerreti C (2000) Recensione di Omero nel Baltico [Review of Homer in the Baltic]. In Bollettino della Società Geografica Italiana, January-June 2000, Roma.

Chiesa Isnardi G (1996) I miti nordici [The Nordic myths]. Milano: Longanesi.

Codino F (1974), Omero, Iliade [Preface, Homer, Iliad]. Torino: Einaudi

Diodoro Siculo (1986) Biblioteca storica [Historical library]. Palermo: Sellero.

Edwards IES, Gadd CJ, Hammond NGL (Eds) (1988) L'apogeo delle civiltà orientali: Egitto, Mesopotamia, Anatolia, Egeo [The apogee of the Eastern civilizations: Egypt, Mesopotamia, Anatolia, Aegean]. Milano: Garzanti.

Finley MI (1979) The World of Odysseus, $2^{\text {nd }}$ edition. London: Penguin Books.

Fischer-Fabian S (1985) I Germani [The Germans]. Milano: Garzanti.

Foster K, Ritner R, Foster B (1996) Texts, storms, and the theraeruption. Journal of Near Eastern Studies 55, 1-14.

Frazer J (1973) Il ramo d'oro [The Golden Bough]. Boringhieri, Torino 1973.

Giannelli G (1983) Trattato di storia greca [Greek history Treaty]. Bologna: Pàtron.

Giumlia-Mair A (2009) Metallurgy around the Baltic between Neolithic and Bronze Age, Iliad and Odyssey in the North of Europe. Proceedings of the Workshop "Toija and the Roots of European Civilisation". Messina: Armando Siciliano.

Giumlia-Mair A (2013) Baltico e Mediterraneo orientale nel II millennio a.C. [Baltic Sea and the eastern Mediterranean in the second millennium B.C.]. In Rivista di Cultura Classica e Medioevale 2(2013). Pisa.

Graf F (1997) Il mito in Grecia [The myth in Greece]. Bari: Laterza.

Hertel D (2003) Troia. Bologna: Il Mulino.

Homer (2013) Iliade. Paris: Gallimard.

Homer (1974) Iliade. Torino: Einaudi.

Homer (1977) Odissea. Torino: Einaudi.

Humbert J (Ed) (1967) Homère, Hymnes. Paris: Les Belles Lettres.

Ilze Rūmniece (2013) Ancient "curetes" and the Western Baltic tribe of "kuri" (some suggestive parallels). In Rivista di Cultura Classica e Medioevale 2(2013). Pisa.

Kerényi (1963) Gli dèi della Grecia [The gods of Greece]. Milano: Il Saggiatore.

Kerényi K (1979) Miti e misteri [Myths and mysteries]. Boringhieri, Torino.

Kirk G (1989) Omero. In La letteratura greca della Cambridge University. Milano: Mondadori.

Koch L, Cipolla MA (Eds) (1993) Saxo Grammaticus. Gesta dei re e degli eroi danesi. Torino: Einaudi.

Lévêque $\mathrm{P}$ (1970) La civiltà greca [The Greek civilization]. Torino: Einaudi.

Markale J (1982) I Celti [The Celts]. Milanoo: Rusconi.

Meier K (Ed) (1886) Merugud Uilix maicc Leirtis. London: Nutti.

Melheim L, Horn C (2014) Tales of Hoards and Swordfighters in Early Bronze Age Scandinavia: The Brand New and the Broken. Norwegian Archaeological Review 47(1): 18-41.

Modzelewski K (2008) L' Europa dei barbari [Barbarians' Europe]. Torino: Bollati Boringhieri.

Montanari F (1992) Introduzione a Omero [Introduction to Homer]. Firenze: Sansoni.

Nilsson MP (1932) The Mycenaean origin of Greek mythology. Berkeley: University of California Press.

Nilsson MP (1933) Homer and Mycenae. London: Metrhuen.

Otte M (2008) La protohistoire [The early history], (2e édition). Bruxelles : De Boeck. Palmer LR (1969) Minoici e Micenei [Minoan and Mycenaean]. Torino: Einaudi. 
Pásztor E (2015) Nebra Disk. In CLN Ruggles (Ed) Handbook of Archaeoastronomy and Ethnoastronomy. New York: Springer.

Piggott S (1968) Ancient Europe. Chicago: Aldine.

Pörtner R (1996) L'epopea dei Vichinghi [The saga of the Vikings]. Milano: Garzanti.

Prampolini G (1954) La mitologia nella vita dei popoli [The mythology in peoples' lives]. Milano: Hoepli.

Raingeard P (ed) (1934) Le PERI TOU PROSOPOU de Plutarque [The PERI TOU PROSOPOU de Plutarque]. Chartres: Imprimerie Durand,.

Randsborg K (1993) Kivik archaeology and iconography. Acta archaeologica 64(1). København.

Renfrew C (1990) Before civilization. The radiocarbon revolution and prehistoric Europe. Harmondsworth: Penguin.

Rivaud A (Ed) (1970) Platon. Timée, Critias. Paris: Les Belles Lettres.

Russell B (1991) Storia della filosofia occidentale [History of western philosophy]. Milano: Longanesi.

Traill DA (1995) Schliemann of Troy: treasure and deceit. New York: St. Martin's.

Tripodi G (2013) Riflessioni naturalistiche sui versi omerici [Natural reflection of the Homeric poems]. Rivista di Cultura Classica e Medioevale 2.

Vidal-Naquet P (1991) Omero, Iliade [Homer, Iliad]. Torino: Einaudi.

Vidal-Naquet P (2013) Homère, Iliade [Homer, Iliad]. Paris: Gallimard.

Vinci F (2006) The baltic origins of Homer's epic tales. Rochester (VT): Inner Traditions.

Vinci F (2016) Homère dans la Baltique [Homer in the Baltic]. Paris: Astrée.

Zanà B (1992) Leggende del popolo curdo [Legends of the Kurdish people]. Milano: Arcana. 
